\title{
Reclamation: Returning to matrilineal traditions, building a new generation of indigenous Girl Societies
}

\author{
Kelly Hallman \\ Population Council \\ Stephanie Martinez \\ Lisa Polen \\ Population Council \\ Angel del Valle \\ Population Council
}

Follow this and additional works at: https://knowledgecommons.popcouncil.org/departments_sbsr-pgy

Part of the Family, Life Course, and Society Commons, Gender and Sexuality Commons, and the Indigenous Education Commons

How does access to this work benefit you? Let us know!

\section{Recommended Citation}

Hallman, Kelly, Stephanie Martinez, Lisa Polen, and Angel del Valle. 2020. "Reclamation: Returning to matrilineal traditions, building a new generation of indigenous Girl Societies." IMAGEN Brief no. 6. New York: Indigenous Adolescent Girls' Empowerment Network (IMAGEN). 


\section{RECLAMATION}

\section{Returning to Matrilineal Traditions,}

\section{Building a New Generation of}

\section{Indigenous Girl Societies}

\section{IMAGEN Workshop Sioux Falls, South Dakota December 3-5, 2019}




\section{Why Adolescent Indigenous Girls?}

\section{AGE 11-12}

$>\quad$ Native youth rank lowest in United States high school graduation rates

$>1$ in 8 American Indian and Alaska Native (AI/AN) high schoolers report experiencing sexual coercion

$>\quad 1$ in 3 Native American women reports having been sexually assaulted in her lifetime

$>\quad$ Native girls have the highest rate of teen births nationwide compared to other racial groups

$>$ Native girls face high risks of trafficking

When programs treat Native youth as a monolith, vulnerable subgroups of young people and consideration for their lived realities are missed.

There is an urgent need for culturally-grounded programming designed specifically for adolescent indigenous girls.

Right: Workshop participants identified major events in the lives of indigenous girls, by age group, that may present risky situations
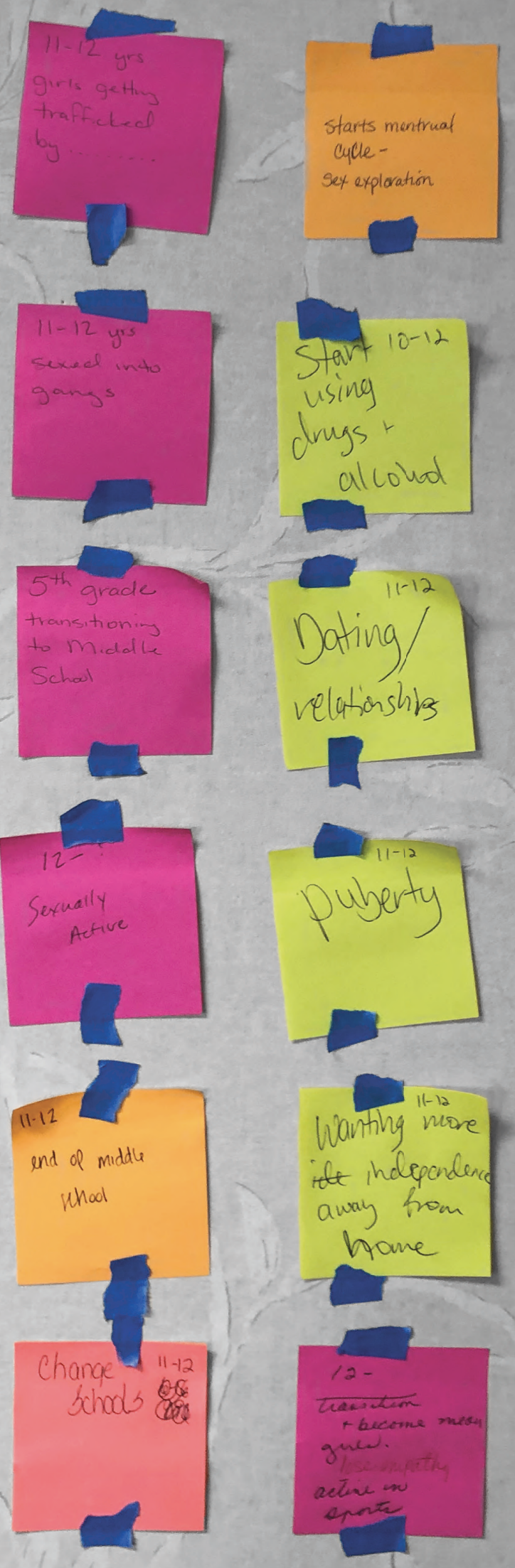


\section{Sioux Falls Workshop}

On December 3-5, 2019, the inaugural cohort of Fellowship Grantee groups convened in Sioux Falls, South Dakota, for a program planning workshop hosted by IMAGEN.

The meeting served as an opportunity for the grantees to formulate plans for community engagement, girl recruitment, mentor training, and material development. The agenda included:

> Envisioning a brighter future for indigenous girls by creating a narrative vision statement

> Exploring the data available globally regarding the risks faced by girls as they transition from girlhood to adolescence, and sharing the unique risks that exist for indigenous girls in the U.S.

$>$ Strategies for identifying girls' strengths and needs, and exploring how these might differ according to age group and household characteristics

$>$ Program planning for safe spaces and methods for engaging stakeholders, including traditional leadership

> Exploring Guatemala's history of systematic exclusion of indigenous populations, and discussing the lessons learned from the Girl Societies set in place there
Participants at the Sioux Falls workshop included:

- Thunder Valley Community

Development Corporation

- Mille Lacs Band of Ojibwe

- 100 Horses Society

- American Indian Family Center

- Oklahoma City Indian Clinic

- White Buffalo Calf Women's Society

- Abriendo Oportunidades

- IMAGEN

Below: Pam Gokey, Jessica Gourneau, Victoria O'Rourke and Sharisse Sitting Bear discuss key steps needed to sustain Girl Societies in the communities

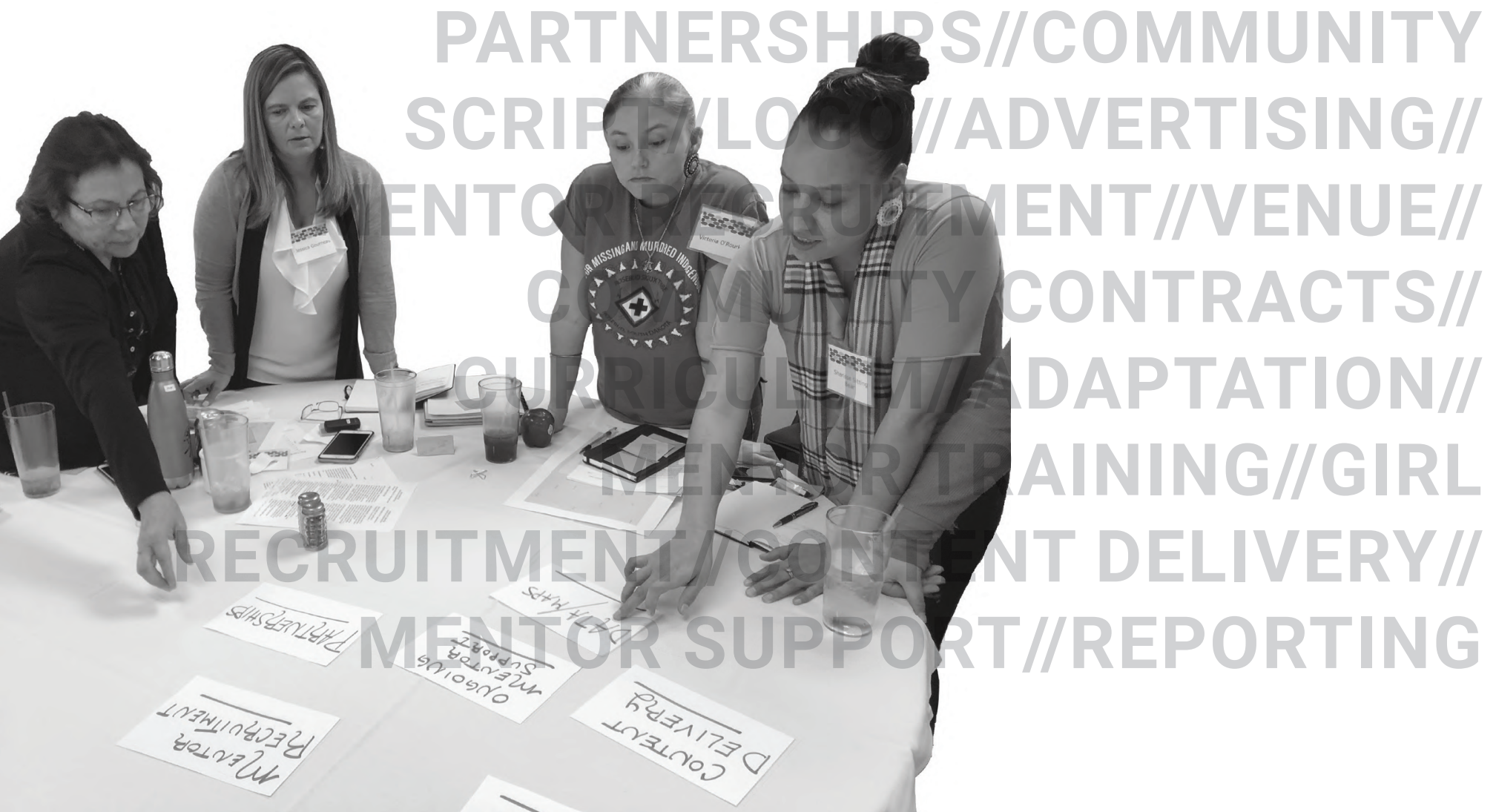




\section{Discovering Shared Histories}

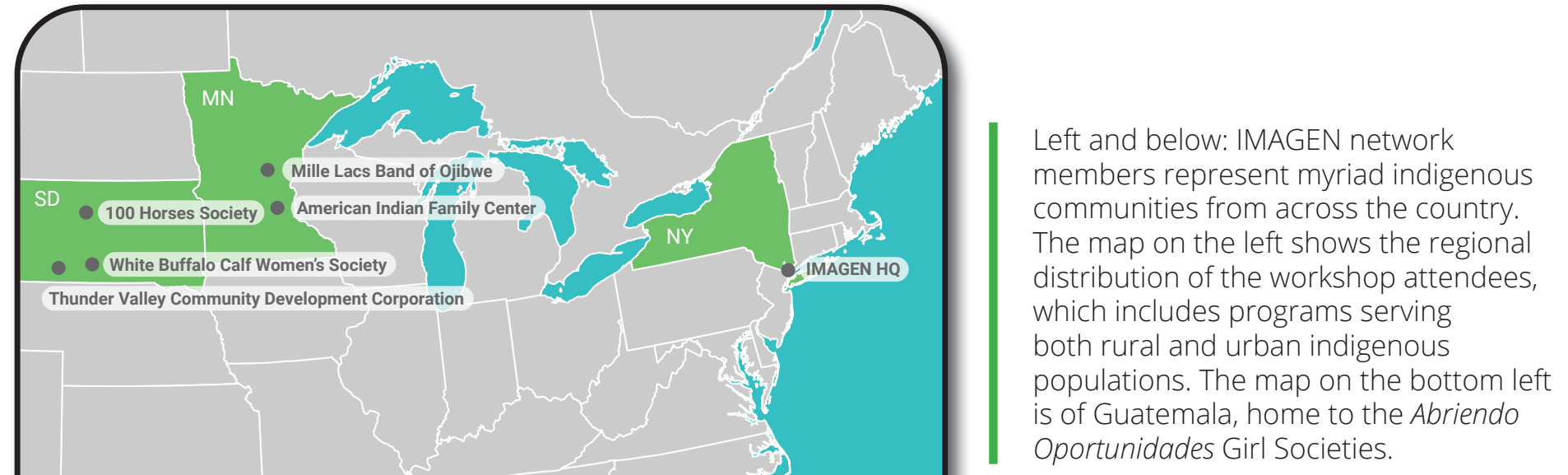

The workshop was honored to have several sessions facilitated by Ángel del Valle, co-founder of the Abriendo Oportunidades program in Guatemala. Abriendo Oportunidades (Opening Opportunities) works with Mayan young women to establish and operate empowerment groups with local adolescent girls. There, girls have the chance to take on leadership roles while learning practical and protective skills that will serve them in their adolescence and adulthood.

Del Valle's discussions provided an opportunity for participants to understand the shared histories of systematic oppression faced by indigenous populations in both Guatemala and the U.S., including

Left and below: IMAGEN network members represent myriad indigenous communities from across the country. The map on the left shows the regional distribution of the workshop attendees, which includes programs serving both rural and urban indigenous populations. The map on the bottom left Oportunidades Girl Societies.

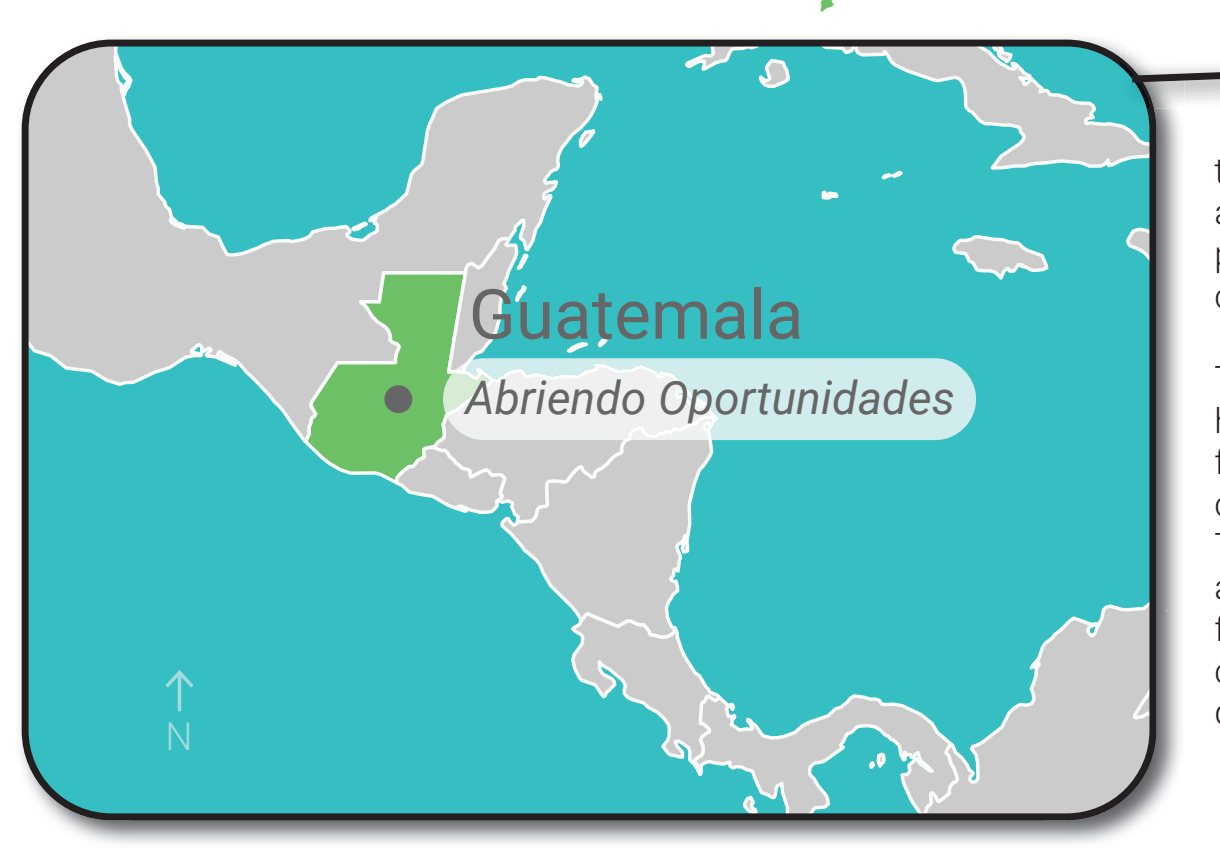

the suppression of knowledge and traditions that were once protective of girls and their communities.

These sessions highlighted how the obstacles currently faced by indigenous girls in both countries mirrored one another. The conversation also identified a potential opportunity in the future to connect girls from both countries in a cross-cultural dialogue about their lived realities. 
